\title{
Recent fluctuation of snow cover on mountainous areas in Japan
}

\author{
Masujiro Shimizu, ${ }^{1}$ Osamu Abe ${ }^{2}$ \\ ${ }^{1}$ Nagaoka Institute of Snow and Ice Studies, National Research Institute for Earth Science and Disaster Prevention (NIED), \\ Nagaoka 940-0821, Japan \\ ${ }^{2}$ Shinjo Branch of Snow and Ice Studies, National Research Institute for Earth Science and Disaster Prevention (NIED), \\ Shinjo 996-0091, Japan
}

\begin{abstract}
To monitor the snow-cover distribution in relation to meteorological conditions on high mountainous areas in Japan, NIED constructed a snow-observation network which it has operated for approximately 10 years. The network consists of seven pairs of stations, each comprising a mountainous site and a low-lying flatland site, from Hokkaido district in the north to San-in in the southwest. Data obtained include snow depth, snow weight, air temperature and global solar radiation. This study presents recent fluctuation of snow cover on mountainous areas for several recent winters in Japan. Most winters were warmer than average, but winter 1995/96 was normal, and maximum snow depths were recorded in high-elevation areas. Seventy-seven avalanche accidents occurred in winter 1995/96. The relationship between meteorological and snow conditions in mountainous areas and flatland areas was analyzed.
\end{abstract}

\section{INTRODUGTION}

For snow- and ice-related disaster-control measures, waterresource management and the monitoring of global fluctuations on a long-term basis, observations of snow-cover fluctuations in mountainous areas are essential where global warming is said to have been progressing.

Continual observation of the snow cover in mountainous areas in Japan is considered difficult, due to the severe conditions of the natural environment. However, the development of measuring instruments and advanced communication technology has enabled us to obtain the data collected at these distant sites.

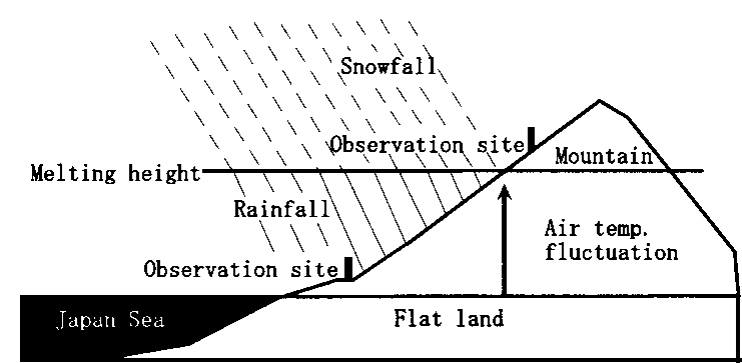

Fig. 1. Conceptual scheme on the configuration of observation sites in mountainous sites and flatland.

Table 1. Location of snow-cover and meteorological observation sites

\begin{tabular}{|c|c|c|c|c|c|}
\hline District & Observation site & Location & $\begin{array}{c}\text { Direct distance } \\
\mathrm{km}\end{array}$ & $\begin{array}{l}\text { Altitude } \\
\text { m.a.s.l. }\end{array}$ & $\begin{array}{c}\text { Altitude difference } \\
\text { m.a.s.l. }\end{array}$ \\
\hline Hokkaido & $\begin{array}{l}\text { Tokachidake Shirogane } \\
\text { Biei }\end{array}$ & $\begin{array}{l}43^{\circ} 29^{\prime} \mathrm{N}, 142^{\circ} 36^{\prime} \mathrm{E} \\
43^{\circ} 36^{\prime} \mathrm{N}, 142^{\circ} 30^{\prime} \mathrm{E}\end{array}$ & 15 & $\begin{array}{l}520 \\
250\end{array}$ & 270 \\
\hline North Tohoku & $\begin{array}{l}\text { Iwakisan } \\
\text { Fujisaki }\end{array}$ & $\begin{array}{l}40^{\circ} 39^{\prime} \mathrm{N}, 140^{\circ} 18^{\prime} \mathrm{E} \\
40^{\circ} 39^{\prime} \mathrm{N}, 140^{\circ} 29^{\prime} \mathrm{E}\end{array}$ & 16 & $\begin{array}{c}1238 \\
20\end{array}$ & 1218 \\
\hline South Tohoku & $\begin{array}{l}\text { Gassan Shizu } \\
\text { Shinjo }\end{array}$ & $\begin{array}{l}38^{\circ} 29^{\prime} \mathrm{N}, 140^{\circ} 00^{\prime} \mathrm{E} \\
38^{\circ} 47^{\prime} \mathrm{N}, 140^{\circ} 19^{\prime} \mathrm{E}\end{array}$ & 43 & $\begin{array}{l}710 \\
127\end{array}$ & 583 \\
\hline East Hokuriku & $\begin{array}{l}\text { Okutadami Maruyama } \\
\text { Nagaoka }\end{array}$ & $\begin{array}{l}37^{\circ} 09^{\prime} \mathrm{N}, 139^{\circ} 14^{\prime} \mathrm{E} \\
37^{\circ} 25^{\prime} \mathrm{N}, 138^{\circ} 53^{\prime} \mathrm{E}\end{array}$ & 42 & $\begin{array}{c}1205 \\
97\end{array}$ & 1108 \\
\hline Central Hokuriku & $\begin{array}{l}\text { Myoko Sasagamine } \\
\text { Takada* }^{*}\end{array}$ & $\begin{array}{l}36^{\circ} 52^{\prime} \mathrm{N}, 138^{\circ} 05^{\prime} \mathrm{E} \\
36^{\circ} 06^{\prime} \mathrm{N}, 138^{\circ} 15^{\prime} \mathrm{E}\end{array}$ & 31 & $\begin{array}{c}1310 \\
13\end{array}$ & 1297 \\
\hline West Hokuriku & $\begin{array}{l}\text { Hakusan Shiramine } \\
\text { Kanazawa* }\end{array}$ & $\begin{array}{l}36^{\circ} 11^{\prime} \mathrm{N}, 136^{\circ} 38^{\prime} \mathrm{E} \\
37^{\circ} 35^{\prime} \mathrm{N}, 136^{\circ} 38^{\prime} \mathrm{E}\end{array}$ & 45 & $\begin{array}{c}835 \\
6\end{array}$ & 829 \\
\hline San-in & $\begin{array}{l}\text { Daisen Kagamiganaru } \\
\text { Houki Mizokuchi }\end{array}$ & $\begin{array}{l}35^{\circ} 20^{\prime} \mathrm{N}, 133^{\circ} 35^{\prime} \mathrm{E} \\
35^{\circ} 18^{\prime} \mathrm{N}, 133^{\circ} 25^{\prime} \mathrm{E}\end{array}$ & 17 & $\begin{array}{l}875 \\
155\end{array}$ & 720 \\
\hline
\end{tabular}

${ }^{*}$ Station of Japan Meteorological Agency. 
NIED established the nationwide mountain snow-observation network between 1988 and 1994, and the snow-cover and meteorological data in the mountainous areas were collected through this network. The recent trend of fluctuations of snow cover in the mountainous areas is discussed here.

\section{OBSERVATION METHOD}

\subsection{Mountain snow-observation network}

This network is composed of seven pairs of observation sites in mountainous and flatland areas throughout Japan (Shimizu and others, 1996; Nakamura and others, 1997). The conceptual scheme is shown in Figure 1. When the temperature during the snowfall season rises due to either a meteorological anomaly or global warming, the winter precipitation in the low-lying flatland areas turns into rain, while it falls as snow in the high-altitude mountainous areas.

Recognizing this phenomenon, simultaneous observations are conducted in both areas. The longitude and latitude of each observation site, the distances in straight lines and altitude differences of the pair-wise observation sites are shown in Table 1, and the locations of the observation sites are shown in Figure 2.

Some of the observation stations in the low-lying flatland areas belong to the Japan Meteorological Agency. The other sites in the Tohoku district and northward areas are managed by the Shinjo Branch of Snow and Ice Studies. The sites in the Hokuriku district and southward areas are managed by the Nagaoka Institute of Snow and Ice Studies.

\subsection{Observation items}

The snow depth, snow weight, air temperature, soil temperature and solar radiation are observed. Hourly observed data are preserved in data loggers. Soil-temperature sensors are installed directly below the metal wafer of the snow-weight meters because the main purpose is to detect the snow cover.

\subsection{Data transmission}

The data collected at the observation sites in the Tohoku district and northward areas, and the Hokuriku district and southward areas, are transmitted from the institutes located in those areas via telephone lines and satellite telephone lines. However, some data are recorded in data loggers and collected after the snowmelt season.

\section{OBSERVATION RESULTS}

\subsection{Annual fluctuations of snow cover}

The fluctuations of the maximum snow cover in the mountainous and low-lying flatland areas during winters 1989/90 through 1998/99 are shown in Figure 3. Since the observation period in Hokkaido, north Tohoku and San-in is short, data from the corresponding observation sites collected by the Japan Meteorological Agency are used. In the mountainous areas ranging from north Tohoku to central Hokuriku, the extreme value of the maximum snow depth was observed in winter 1995/96 (Abe and Shimizu, 1997a, b), and the fluctuation tendency looks similar. However, the fluctuation tendency in the Hokkaido and San-in areas looks different.

In 1995/96, as many as 77 avalanche accidents in Japan were reported by Izumi and Kobayashi (1996).

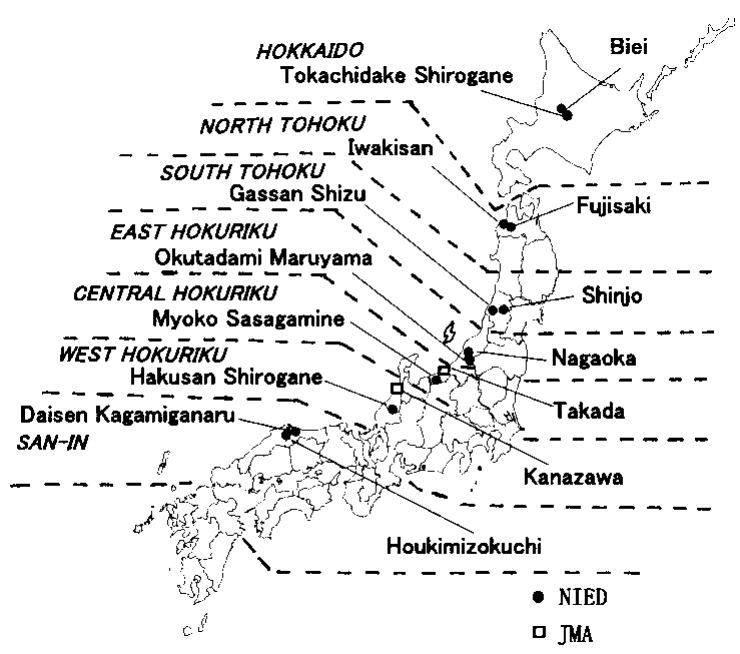

Fig. 2. Location of snow-cover and meteorological observation sites.

In the low-lying flatland areas, large fluctuations of the maximum snow cover are observed, whereas in the mountainous areas the fluctuations are small. This implies that the recent global warming does not make the precipitation turn into rain in the mountainous areas. Nakamura and Shimizu (1996) reported that the winter air temperature in Nagaoka had risen by $1.3^{\circ} \mathrm{C}$ over the last 100 years. As shown later in Figure 5, due to the temperature lapse rate the winter air temperature in the mountainous areas $>800$ m a.s.l. remains below freezing, even with the temperature rise of $1-2^{\circ} \mathrm{C}$. Therefore, it can be said that the winter precipitation continues to fall as snow in the mountainous areas where the winter monsoon brings precipitation. Further observations will be conducted in San-in (mild weather) and Hokkaido (cold weather) to investigate whether similar phenomena are also observed in these areas.

The approximate linear equation and the correlation coefficient between the snow depth of Nagaoka and that of Okutadami, both located in the same district as shown in Figure 3, are given as follows:

$$
O=0.56 N+435 \quad r^{2}=0.2
$$

where $O(\mathrm{~m})$ and $N(\mathrm{~m})$ are the annual maximum snow depths of Okutadami and Nagaoka, respectively. The fluctuation of the annual maximum snow depth in Nagaoka over a period of about 100 years was reported by Nakamura and Shimizu (1996). According to the estimate based on Equation (1), the annual maximum snow depth in Okutadami has varied over the past 100 years from 4.5 to $6.2 \mathrm{~m}$, and the area had less snow during the recent period 1988-95.

The World Data Center for Glaciology has issued a report on the interannual fluctuation of the snow-covered area in the Northern Hemisphere (Barry and others, 1993). A comparison was made between this report and the data of snow depth in Nagaoka and estimated snow depth in Okutadami. The snowcovered area of the Northern Hemisphere in the spring season for the 20 years from 1972 to 1992 has decreased by approximately $9 \%$. During this same period, snow depth in Nagaoka has decreased by $30 \%$ and that of Okutadami is estimated to have decreased by $4 \%$. It can be said that snow depth in Japan varies in accordance with the snow depth in the Northern Hemisphere. 

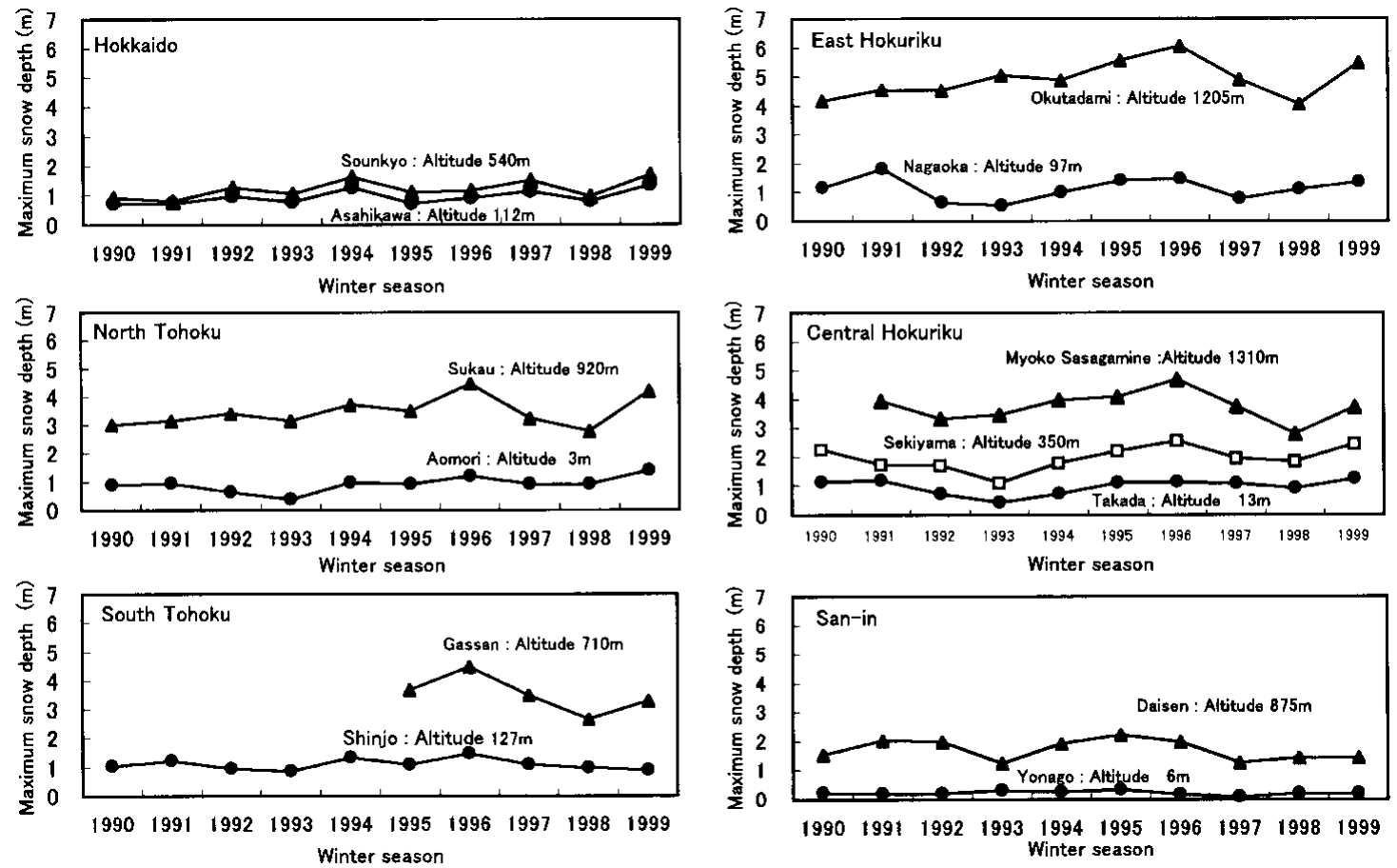

Fig. 3. Fluctuation of annual maximum snow depth in mountainous areas and flatland.

\subsection{Correlation between sites}

\subsubsection{Snow cover}

Figure 4 shows the cross-correlation coefficients of the maximum snow depth between the adjoining mountainous areas in south Tohoku and east Hokuriku, and between Gassan (the mountainous area of south Tohoku) and Shinjo (the low-lying flatland area of south Tohoku). The cross-coefficient in this figure is normalized by the coefficient with time lag of 0 year (Hino, 1985).

Although Figure 4 shows that the observation period is not sufficiently long, favorable correlations are observed between south Tohoku and east Hokuriku Gassan and Okutadami) since its cross-correlation shows a steeper peak than that between the mountainous area and the flatland area in south Tohoku (Gassan and Shinjo). This phenomenon seems to be due to the fact that the snow cover in the mountainous area is governed by the synoptic field of the winter monsoon.

\subsubsection{Average daily air temperature}

In order to estimate the weather conditions in the mountainous areas from those of the low-lying flatland areas, the correlations between these areas are required. Figure 5 shows the results of examinations of the correlations of average daily air temperature between the seven mountainous and flatland areas throughout Japan during the four winter seasons 1992/93 to 1995/96. The original data are provided by Abe and Shimizu (2000). The straight lines in Figure 5 are regression equations obtained by the least-squares method; $a$ is a gradient of the regression equation; $b$ is the temperature in the mountainous area corresponding to $0^{\circ} \mathrm{C}$ in the flatland areas. The standard deviation $(\sigma)$ which shows the variance and data number is also indicated in Figure 5.

While $a=0.93-1.18, b$ is small, corresponding to the altitude difference between the mountainous areas and the flatland areas. It can be seen that they are in proportion to each other. The smallest standard deviation is $1.1^{\circ} \mathrm{C}$ in Hokkaido, which has the shortest distance of $15 \mathrm{~km}$ in a straight line between observation sites. Although the distance of $16 \mathrm{~km}$ in a straight line in the north Tohoku area is fairly short, the standard deviation of $2^{\circ} \mathrm{C}$ is not as small. This is attributed to the fact that the relationship between the standard deviation and the straight-line distance is affected not only by the distance but also by other geographical features.

\subsection{Mean density}

For calculating the rooftop snow load of buildings to be constructed in the mountainous areas, the mean density of snow cover is required for estimating snow weight from the snow depth. This snow-observation network provides the density calculated from snow depth and snow weight as follows:

$$
\rho=\frac{\mathrm{MW}}{\mathrm{HS}},
$$

where $\rho$ is the whole-layer mean density $\left(\mathrm{kg} \mathrm{m}^{-3}\right), \mathrm{MW}$ is the snow weight $\left(\mathrm{kg} \mathrm{m}^{-2}\right)$ and HS is the snow depth $(\mathrm{m})$.

Table 2 shows the whole-layer mean densities at the time of the maximum snow depth and the maximum snow weight

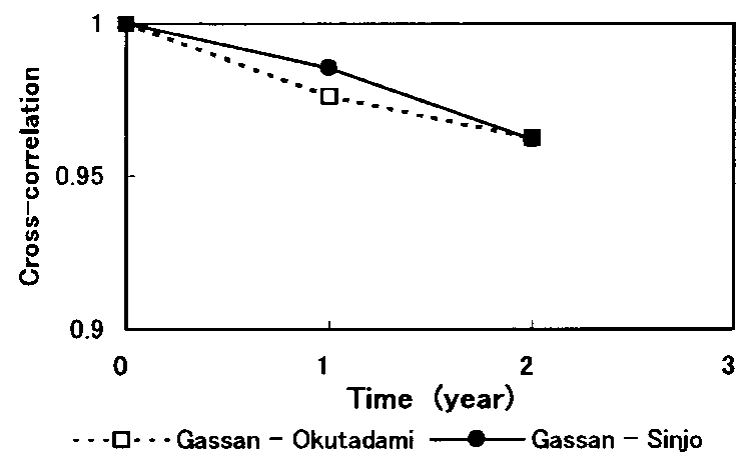

Fig. 4. Cross-correlation between observation sites on annual maximum snow depth. 
Table 2. Annual maximum snow depth and mean density at maximum snow-depth times, winter 1995/96

\begin{tabular}{|c|c|c|c|c|c|c|c|}
\hline & Hokkaido & North Tohoku & South Tohoku & East Hokuriku & Central Hokuriku & West Hokuriku & San-in \\
\hline Mountainous site: & $\begin{array}{c}\text { Tokachidake } \\
\text { Shirogane }\end{array}$ & Iwakisan & Gassan Shizu & $\begin{array}{l}\text { Okutadami } \\
\text { Maruyama }\end{array}$ & $\begin{array}{c}\text { Myoko } \\
\text { Sasagamine }\end{array}$ & $\begin{array}{l}\text { Hakusan } \\
\text { Shiramine }\end{array}$ & $\begin{array}{c}\text { Daisen } \\
\text { Kagamiganaru }\end{array}$ \\
\hline Maximum snow depth $(\mathrm{cm})$ & 129 & 286 & 450 & 605 & 467 & 286 & 276 \\
\hline Snow weight on same day $\left(\mathrm{kg} \mathrm{m}^{-2}\right)$ & - & 593 & 1830 & 2203 & 1981 & 1130 & 811 \\
\hline Mean density on same day $\left(\mathrm{kg} \mathrm{m}^{-3}\right)$ & - & 207 & 407 & 364 & 424 & 395 & 294 \\
\hline Date & 23 March & 24 February & 10 March & 4 February & 5 March & 10 February & 10 February \\
\hline Maximum snow weight $\left(\mathrm{kg} \mathrm{m}^{-2}\right)$ & - & 720 & 1960 & 2939 & 2284 & 1388 & 945 \\
\hline Snow depth on same day $(\mathrm{cm})$ & - & 246 & 398 & 512 & 417 & 209 & 239 \\
\hline Mean density on same day $\left(\mathrm{kg} \mathrm{m}^{-3}\right)$ & - & 293 & 492 & 574 & 548 & 664 & 395 \\
\hline Date & - & 24 March & $18 \mathrm{March}$ & 21 April & 18 March & 17 March & $6 \mathrm{March}$ \\
\hline Flatland site: & Biei & Fujisaki & Shinjo & Nagaoka & Takada & Kanazawa & Houki Mizohuchi \\
\hline Maximum snow depth $(\mathrm{cm})$ & 70 & 88 & 146 & 144 & 111 & 21 & 38 \\
\hline Mean density on same day $\left(\mathrm{kg} \mathrm{m}^{-3}\right)$ & 331 & 273 & 244 & 198 & - & - & - \\
\hline Date & 23 March & 24 February & 2 February & 2 February & 3 February & 3 February & 10 February \\
\hline Maximum snow weight $\left(\mathrm{kg} \mathrm{m}^{-2}\right)$ & 234 & 260 & 439 & 386 & - & - & - \\
\hline Snow depth on same day $(\mathrm{cm})$ & 60 & 78 & 114 & 118 & - & - & - \\
\hline Mean density on same day $\left(\mathrm{kg} \mathrm{m}^{-3}\right)$ & 390 & 333 & 385 & 327 & - & - & - \\
\hline Date & 26 March & 11 February & 13 February & 24 February & - & - & - \\
\hline
\end{tabular}

during winter 1995/96. The whole-layer mean density at the time of the maximum snow weight is larger than that at the time of the maximum snow depth at all the observation sites in both the mountainous and the low-lying flatland areas. This observation can be explained through comparisons between the dates when maximum snow weight and depth are observed. The maximum snow-weight observing dates are usually later than the maximum snow-depth observing dates, and the consolidation process takes place during this period. The time lag of these two phenomena is greater in the mountainous areas than in low-lying flatland areas.

Figure 6 shows the distribution of maximum snow depth and whole-layer mean density at the time of maximum snow depth. The maximum snow depth in the mountainous areas was $605 \mathrm{~cm}$, observed at Okutadami in east Hokuriku, while the maximum mean density was $424 \mathrm{~kg} \mathrm{~m}^{-3}$, observed at Myoko in central Hokuriku.

The mean density in the low-lying flatland areas, though not recorded in the central Hokuriku district and southward areas, is higher in the northern areas. This is probably because of the late occurrence date of the maximum snow depth in the northern areas, with densification progressing accordingly.

According to Shinojima (1967), the densification of the snow generally progresses greatly when the elapsed time is longer, or the overlying load is greater, or the temperature is close to $0^{\circ} \mathrm{C}$. It is then considered that the maximum values of mean density are observed, in the mountainous area, in the central Hokuriku district with mild climate and heavy snow cover, and in the low-lying flatland area, at the cold Hokkaido with longer elapsed time.

\section{SUMMARY}

The observations and data analysis conducted through the
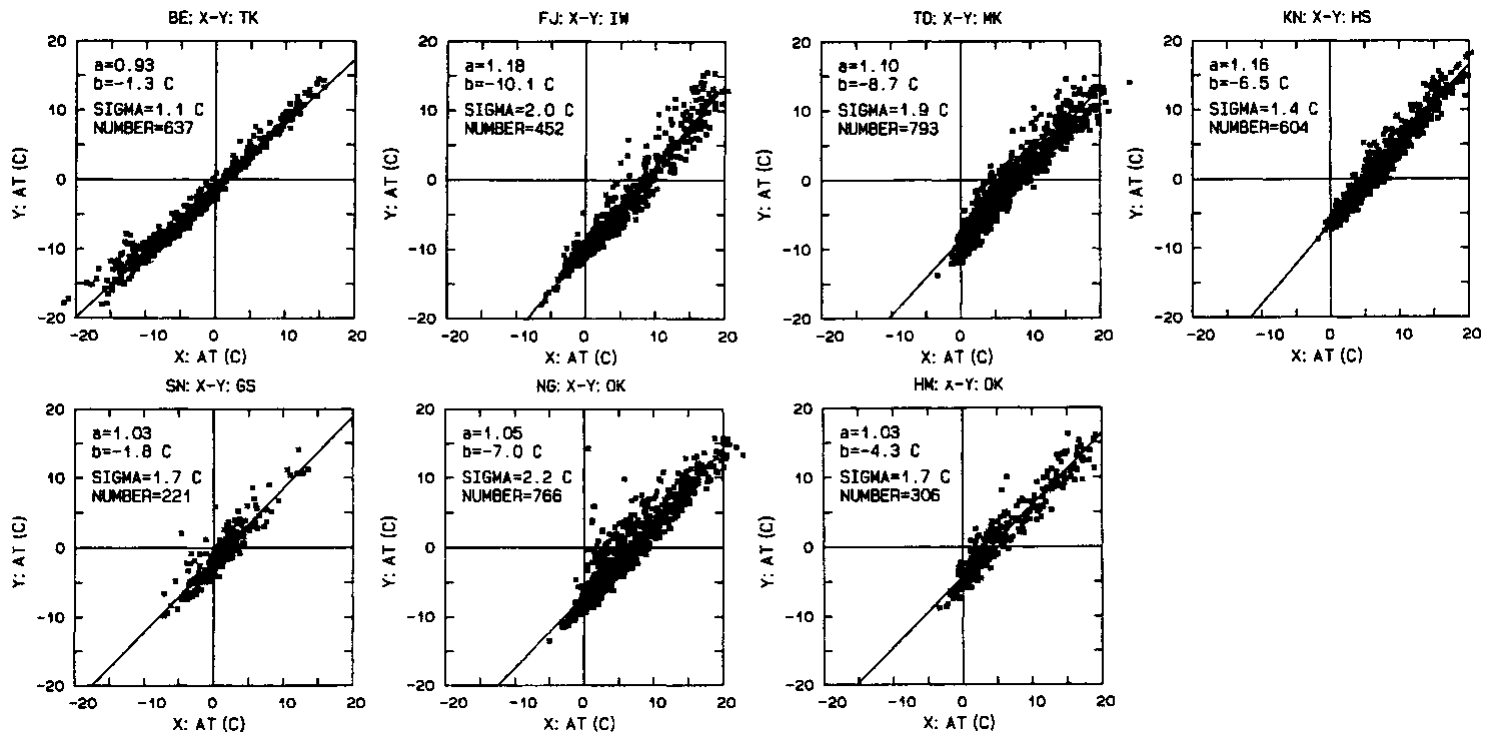

Fig. 5. Correlation of the daily mean air temperature between mountainous areas and flatlands. 


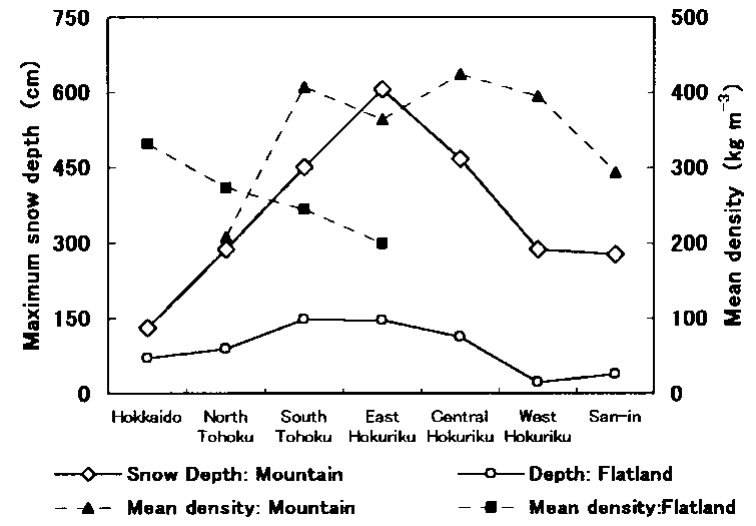

Fig. 6. Distribution of maximum snow depth and mean density in mountainous areas and flatlands.

mountain snow-observation network have revealed the following:

The remarkable decrease of maximum snow depth observed in the low-lying flatland areas has not been observed in the mountainous areas. However, continual data collection is necessary in order to reach a definite conclusion.

In adjoining south Tohoku and east Hokuriku districts, the correlation of annual fluctuation of the maximum snow depth was examined. The adjoining mountainous areas showed slightly more favorable correlation than did the mountainous and flatland areas in the same region. This phenomenon is attributed to the fact that the mountainous snow is governed by the synoptic field of the winter monsoon.

The correlation of daily mean temperature between the low-lying flatland and mountainous areas in each region was fairly good. The degree of correlation, favorable or unfavorable, is affected not only by the distances in straight lines but also by geographical features.

The regional distribution of the mean density at the maximum snow depth shows highest values in the warm central Hokuriku district, with heavy snow cover, and in the cold Hokkaido area, representing the mountainous and low-lying flatland areas, respectively.

\section{ACKNOWLEDGEMENTS}

For the observations in flatland areas, data collected by Takada Meteorological Station and Kanazawa Local Meteorological Observatory were used, along with the data of Tottori Prefecture and Hokkaido, which were collected by the Japan Meteorological Agency. The data of Shinjo and Nagaoka collected by the Shinjo Branch of Snow and Ice Studies and Nagaoka Institute of Snow and Ice Studies were used. We express our appreciation in mentioning the names above.

\section{REFERENGES}

Abe, O. and M. Shimizu. 1997a. [Recent fluctuation of snowcover on mountain areas in Japan.] In Cold Region Technology Conference '99, 1999, Sapporo, Japan. Proceedings. Sapporo, Hokkaido Development Technology Center, 21-25. [In Japanese.]

Abe, O. and M. Shimizu. 1997b. [Snowcover variation at 1995/96 winter in mountainous areas of Japan.] Touhoku no Yuki to Seikatsu, 1977(12), 22-25. [In Japanese.]

Abe, O. and M. Shimizu. 2000. [Snow distribution and meteorological data (2).] Nat. Res. Inst. Earth Sci. Disaster Prev. Tech. Note 201. [InJapanese with English abstract.]

Barry, R. G., B. E. Goodison and E. F. LeDrew. 1993. Snow Watch'92: Detection Strategies for Snow and Ice: Proceedings, International Workshop on Snow and Lake Ice Cover and the Climate System, 29 March-1 April 1992, Niagara-on- theLake, Ontario. Boulder, CO, University of Colorado. (Glaciological Data Report GD-25.)

Hino, M. 1985. [Cross-correction and cross spectrum.] In [Spectrum analysis ]. Tokyo, Asakura Publishing Company, 52-66. [In Japanese.]

Izumi, K. and S. Kobayashi. 1996. [Avalanche disaster in Japan in the winter 1995/96.] In 1996 Japanese Society of Snow and Ice Conference. Preprint. Tokyo, Japanese Society of Snow and Ice, 35. (Lecture 135.) [In Japanese.]

Nakamura, T. and M. Shimizu. 1996. Variation of snow, winter precipitation and winter air temperature during the last century at Nagaoka, Japan. 7. Glaciol., 42(140), 136-140.

Nakamura, H., M. Shimizu, O. Abe, T. Kimura, M. Nakawo and T. Nakamura. 1997. A snow observation network for mountain area of NIED. In Izumi, M., T. Nakamura and R. L. Sack, eds. Snow engineering: recent advances. Rotterdam, A. A. Balkema, 539-541.

Shimizu, M., M. Nakawo, T. Kimura, S. Takami, H. Iida and N. Miyazaki. 1996. [Snow distribution and meteorological data (1).] Nat. Res. Inst. Earth Sci. Disaster Prev. Tech. Note 173. [InJapanese with English summary.]

Shinojima, K. 1967. Study on the visco-elastic deformation of deposited snow. In Oura, H., ed. Physics of snow and ice. Vol. 1, Part 2. Sapporo, Hokkaido University. Institute of Low Temperature Science, 875-907. 